\title{
BIOLOGICAL FERTILIZER AND COVER PLANTS ON SOIL ATTRIBUTES AND MAIZE YIELD ${ }^{1}$
}

\author{
JOÃO PAULO ASCARI²*, DEJÂNIA VIEIRA DE ARAÚJO² ${ }^{2}$ INÊS ROEDER NOGUEIRA MENDES ${ }^{3}$, RIVANILDO \\ DALLACORT $^{2}$, LEOPOLDO SUSSUMU MATSUMOTO ${ }^{4}$
}

\begin{abstract}
Maize is an important crop for Brazil's economy. This species is, in general, grown as monoculture, making it necessary the use of conservationist practices for soil management and to favor crop development. The objective of this study was to evaluate the effects of biological fertilizer and cover plants on soil properties and maize yield. The experiment was conducted in a dystrophic Latossolo Vermelho (Oxisol), in the 2015-2016 and 2016-2017 crop seasons in Tangará da Serra, MT, Brazil. The experiment was conducted in a randomized block design, using a double factorial arrangement with an additional control: two biological fertilizer conditions, three soil cover conditions, and a control (forest fragment). Seeds of Pennisetum glaucum and Crotalaria ochroleuca were sowed on October 2015 and 2016. Maize seeds were sowed on December 2015 and 2016, with subsequent application of $150 \mathrm{~L} \mathrm{ha}^{-1}$ of biological fertilizer. The soil cultivated with maize had greater chemical quality than that under the forest fragment, however, the forest fragment soil had greater microbiological quality. The use of biological fertilizer and cover plants increased the fertility and microbiological quality of the soil cultivated with maize. The use of cover plants increased the maize yield in both crop seasons. The use of biological fertilizer and soil cover plants ( $P$. glaucum and C. ochroleuca) improved the soil chemical and microbiological quality.
\end{abstract}

Keywords: Soil fertility. Microbiological quality. Zea mays.

\section{FERTILIZANTE BIOLÓGICO E PLANTAS DE COBERTURA NOS ATRIBUTOS DO SOLO E PRODUTIVIDADE DO MILHO}

RESUMO - O milho é uma importante cultura para a economia brasileira, porém, é produzido em sistema de monocultura, e por isso, torna-se necessário o uso de práticas conservacionistas de manejo do solo que favoreçam o desenvolvimento da cultura. $\mathrm{O}$ objetivo deste estudo foi avaliar os efeitos da adubação biológica e plantas de cobertura nas propriedades do solo e produtividade do milho. O experimento foi conduzido em um LATOSSOLO VERMELHO distrófico (Oxisols dystrofphic), nas safras 2015/16 e 2016/17 em Tangará da Serra - MT, Brasil. O delineamento experimental foi em blocos casualizados, em esquema fatorial duplo com controle adicional: duas condições de adubação biológica, três condições de cobertura do solo e um controle (fragmento de mata). A semeadura do Pennisetum glaucum e da Crotalaria ochroleuca foi realizada em outubro de 2015 e 2016. A semeadura do milho ocorreu em dezembro de 2015 e 2016, seguida da aplicação de $1501 \mathrm{ha}^{-1}$ de fertilizante biológico. O solo cultivado com milho apresentou maior qualidade química em relação ao solo do fragmento de mata, não obstante, obteve menor qualidade microbiológica. A adubação biológica e as plantas de cobertura incrementaram a fertilidade e a qualidade microbiológica do solo cultivado com milho. As plantas de cobertura incrementaram a produtividade do milho em ambas as safras. Com isso, a adubação biológica e a plantas de cobertura $P$. glaucum, and $C$. ochroleuca aumentaram a qualidade química e microbiológica do solo.

Palavras-chave: Fertilidade do solo. Qualidade microbiológica. Zea mays.

\footnotetext{
${ }^{*}$ Corresponding author

${ }^{1}$ Received for publication in $08 / 31 / 2018$; accepted in $07 / 31 / 2019$.

Extracted from the master thesis of the first author.

${ }^{2}$ Agronomy Department, Universidade do Estado de Mato Grosso, Tangará da Serra, MT, Brazil; joaoascari321@gmail.com - ORCID: 0000-0002-1207-5806, dejania@unemat.br - ORCID: 0000-0003-4577-8580, rivanildo@unemat.br-ORCID: 0000-0002-7634-8973.

${ }^{3}$ Empresa Mato-grossense de Pesquisa, Assistência e Extensão Rural, Campo Novo do Parecis, MT, Brazil; ynes2nogueira@gmail.com ORCID: 0000-0001-8862-5758.

${ }^{4}$ Agronomy Department, Universidade Estadual do Norte do Paraná, Bandeirantes, PR, Brazil; leopoldo@uenp.edu.br - ORCID: 0000$0001-5102-545 X$.
} 


\section{INTRODUCTION}

Brazil is the world's third largest maize producer. Maize is the most important cereal in the Mato Grosso State, where it is grown mainly as a second crop, usually after soybean crops; this crop presented grain production of $30,093.7 \mathrm{Mg}$ (approximately $42.6 \%$ of the national production) and average yield of $6,232.0 \mathrm{~kg} \mathrm{ha}^{-1}$ in the 2018 2019 crop season (CONAB, 2019).

The monoculture system can change soil properties, usually by decreasing its biological, physical, and chemical quality. It can affect crop development, reducing grain yield. Soil management practices in agriculture has changing because of the need for new techniques that increase the fertilizer efficiency and crop yield, and they contribute for the soil conservation and sustainability of agroecosystems (ANDREOTTI et al., 2008; JAKELAITIS et al., 2008).

Soil fertility is low in the monoculture system, mainly because of reductions in soil nitrogen contents. Thus, crop rotation is recommended as an alternative practice to minimize agricultural impacts on soil quality. The no-tillage system is another alternative conservationist practice that makes agriculture viable from the economic and environmental point of view. Crop rotation with soil cover plants, whose biomass remains on the soil for long time, maintains the soil protected. Plant species used as green manure are good options for soil cover in the Brazilian Cerrado biome (ANDREOTTI et al., 2008; ZERIHUN; HAILE, 2017).

Soil cover plants must have high biomass production. Millet (Pennisetum spp.) has high dry matter production and nutrient cycling, which are important for making potassium, phosphorus, nitrogen, calcium, and sulfur available to the soil (BOER et al., 2007). Crotalaria (Crotalaria spp.) also has high biomass production and assists in biological nitrogen fixation (TORRES et al., 2008). These soil cover plants have a high potential for use in the no-tillage system due to their dry matter production capacity and gradual nutrient release to the soil (PERIN et al., 2010).

The addition of plant residues to the soil contributes to the soil organic matter. The soil organic matter improves soil biology and soil physicochemical properties by increasing the soil organic carbon, cation exchange capacity, microbial activity, nutrient cycling, and nutrient availability. It also improves the soil physical structure, establishment of microorganisms responsible for organic matter decomposition, and organic carbon fixation, maintaining the soil with long-term productive capacity (JAKELAITIS et al., 2008; BHARDWAJ et al., 2011; CAPUANI et al., 2012).

The effect of these practices is monitored using the soil microbiological and chemical properties. Microbiological indicators are sensitive to environmental changes, and microorganisms have a complex interaction with the soil. Thus, a joint analysis of microbiological and chemical indicators is necessary (CARNEIRO et al., 2009).

The soil microbial biomass is important for agricultural soils and is a sensitive indicator of soil quality change in agricultural systems regarding the fertilizer type and soil management practices used (HARGREAVES et al., 2003; LIU et al., 2014). Biological fertilizers contribute to the soil microbial diversity. These organic compounds are rich in minerals that favor the increase and establishment of microbial populations in the soil (MEDEIROS; LOPES, 2006).

The addition of organic matter to the soil makes the use of mineral fertilizers more efficient, and is a viable practice to increase soil organic matter and microbial biomass, which contributes to the conservation of agroecosystems and reduces the impacts of agriculture on the soil biodiversity (BHARDWAJ et al., 2011; XU et al., 2018).

The use of biological fertilizers in maize crops results in high agronomic performance and number of ears per square meter. The addition of organic matter by soil cover plants associate with biological and/or mineral fertilizers has presented satisfactory results in long-term management, increasing grain yield and improving soil properties. Therefore, it can be an important tool to minimize impacts on soil structure (BEZERRA et al., 2008; ABERA et al., 2009; XU et al., 2018).

In this context, the hypothesis of the present study is that the combined use of biological fertilizer and cover plants increases physical and microbiological properties of soils cultivated with maize as second crop. Thus, the objective of this study was to evaluate the effects of biological fertilizer and cover plants on soil properties and maize yield.

\section{MATERIAL AND METHODS}

The experiment was carried out in two crop seasons, 2015-2016 and 2016-2017, at the experimental area of the Mato Grosso State University, in Tangará da Serra, Brazil (14.6323662065, -57.4685632572). The experimental area had been cultivated with cotton (Gossypium hirsutum L.) in the previous five crop seasons using conventional planting system, with two harrowing operations per season. The soil of the experimental area was classified as a dystrophic Latossolo Vermelho (Oxisol) (EMBRAPA, 2013). The meteorological data were monitored during the two crop seasons by an automatic station installed near the experimental area $(500 \mathrm{~m})$ (Figure 1).

The experiment was conducted in a randomized block design, using a double factorial arrangement with an additional control and four 
replications. The treatments consisted of two fertilization conditions (with and without biological fertilizer), three soil cover conditions - millet Pennisetum glaucum (L.) R. Br.; crotalaria (Crotalaria ochroleuca G. Don.); and a fallow area - and a control (forest fragment). The native forest fragment was used as control to evaluate the soil chemical and microbiological quality.

Before the experiment installation, $1,300 \mathrm{~kg}$ $\mathrm{ha}^{-1}$ of limestone was applied and incorporated into the soil using a leveling disc harrow, following the recommendations of Sousa and Lobato (2004).

The plots were $5.0 \mathrm{~m}$ long and $5.0 \mathrm{~m}$ wide. Seeds of the soil plant covers were distributed and incorporated into the soil with a leveling disc harrow, shortly after the onset of rains (October 3, 2015 and 2016) (Figure 1). The millet seeds (ADR500 cultivar) were sowed using $25 \mathrm{~kg} \mathrm{ha}^{-1}$, and the crotalaria seeds (Common cultivar) were sowed using $15 \mathrm{~kg} \mathrm{ha}^{-1}$; the plants were chemically killed at 50 and 65 days after sowing (DAS), respectively. The fallow plots were kept free from weeds during the period between harvests; no weed control was done during the soybean season to show the responses of the soil properties without any cover plants and compare with the soil with cover plants.

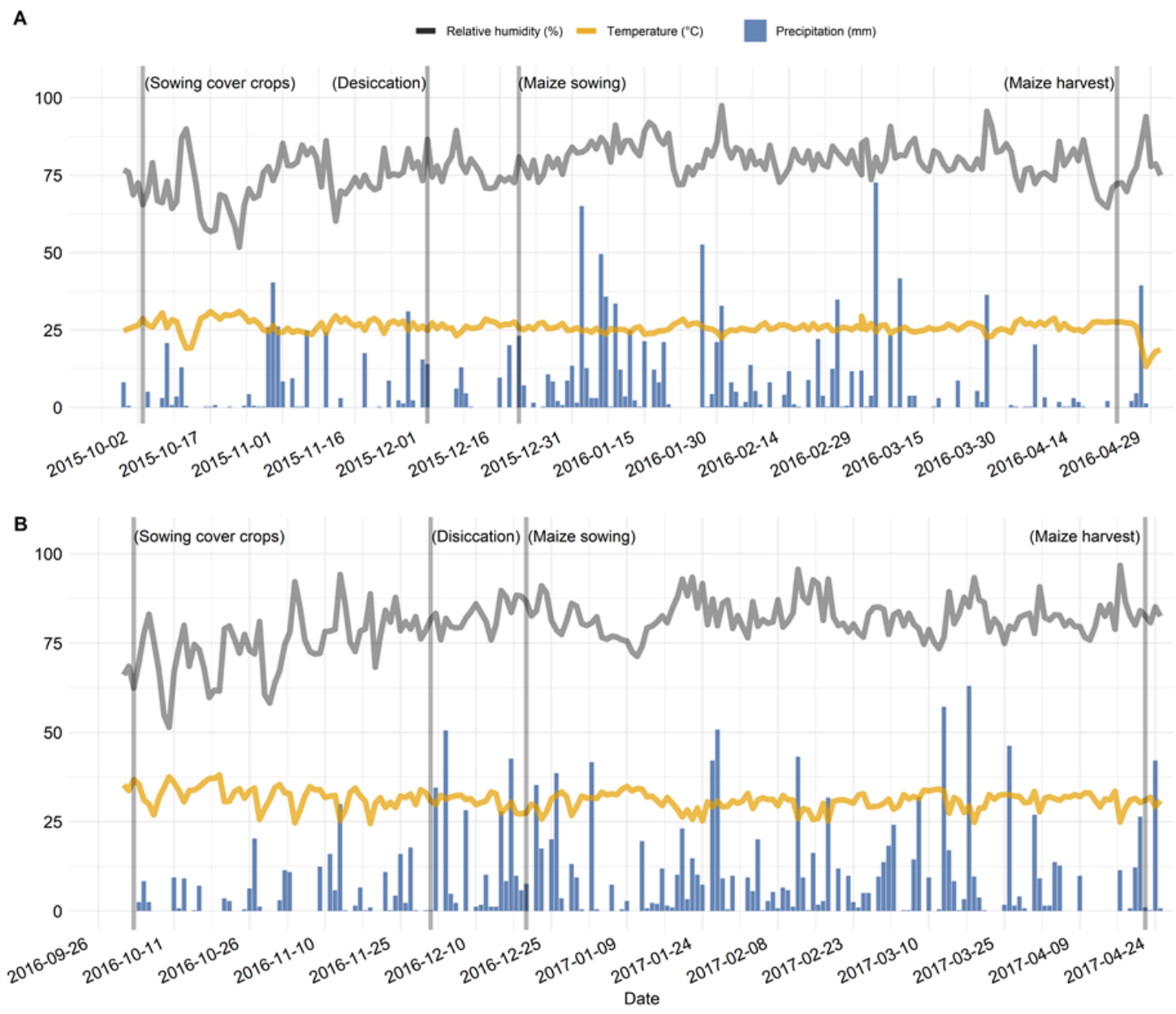

Figure 1. Accumulated precipitation $\left(\mathrm{mm}^{-1}\right)$, average temperature $\left(\mathrm{T}^{\circ} \mathrm{C}\right)$, and relative air humidity $(\%)$ in the experimental field in the 2015-2016 (A) and 2016-2017 (B) crop seasons

The maize seeds (AS1555 cultivar) were sowed under no-tillage system on December 20, 2015 and 2016, with spacing of $0.5 \mathrm{~m}$ between rows and density of 55,000 plants ha $^{-1}$. Fertilization at sowing consisted of $550 \mathrm{~kg} \mathrm{ha}^{-1}$ of MAP $\left(51 \% \mathrm{P}_{2} \mathrm{O}_{5}\right.$ plus $9 \% \mathrm{~N})$ and $85 \mathrm{~kg} \mathrm{ha}^{-1}$ of $\mathrm{KCl}\left(60 \% \mathrm{~K}_{2} \mathrm{O}\right)$. Topdressing consisted of $155 \mathrm{~kg} \mathrm{ha}^{-1}$ urea $(45 \% \mathrm{~N})$ and $50 \mathrm{~kg} \mathrm{ha}^{-1} \mathrm{KCl}$ at 20 DAS, according to recommendations of Sousa and Lobato (2004). Micronutrients were applied via foliar at 30 DAS, using $1.5 \mathrm{~L} \mathrm{ha}^{-1}$ of Platon- $25^{\circledR}$.
The biological fertilizer was prepared in a plastic container by mixing $20 \mathrm{~L}$ water, $4 \mathrm{~L}$ bovine manure, and $1 \mathrm{~kg}$ of the biological compound. It was left for fermentation for 60 days. Its mineral properties at the time of application are shown in Table 1. The biological properties of this compound consisted mainly of bacteria and fungi as described by the manufacturer (MEDEIROS; LOPES, 2006). The biological fertilizer was applied 24 hours after the maize sowing using $150 \mathrm{~L} \mathrm{ha}^{-1}$. 
Table 1. Chemical characteristics of the biological fertilizer used in the experiment.

\begin{tabular}{|c|c|c|c|c|c|c|c|c|c|c|c|}
\hline \multicolumn{12}{|c|}{ Chemical characteristics } \\
\hline $\mathrm{pH}$ & $\mathrm{N}$ & $\mathrm{P}$ & $\mathrm{K}$ & $\mathrm{Ca}$ & $\mathrm{Mg}$ & $\mathrm{S}$ & $\mathrm{Zn}$ & $\mathrm{Cu}$ & $\mathrm{Fe}$ & B & $\mathrm{OM}$ \\
\hline $\mathrm{H}_{2} \mathrm{O}$ & -- & --- & ---- g & --o- & & & --- & -- & $c^{-1}-$ & - & $\%$ \\
\hline 6.2 & 0.71 & 0.3 & 0.02 & 0.06 & 0.01 & 0.04 & 4.7 & 2.8 & 175 & 14.4 & 5.2 \\
\hline
\end{tabular}

The soil chemical and microbiological properties were evaluated at 120 days after the maize sowing. A Dutch auger was used to collect five simple soil samples of each plot from between the maize rows, and soil samples from the forest fragment, forming composite samples for each replication.

Soil samples from the $0-0.20 \mathrm{~m}$ layer were collected to analyze the following soil chemical properties, according to Embrapa (2011): organic matter $(\mathrm{OM}), \mathrm{pH}$, phosphorus $(\mathrm{P})$, potassium $(\mathrm{K})$, calcium (Ca), magnesium $(\mathrm{Mg})$, hydrogen + aluminum $(\mathrm{H}+\mathrm{Al})$, and cation exchange capacity (CEC).

Soil samples from 0-0.10 $\mathrm{m}$ layer were collected for microbiological analysis to determine the following properties: a) soil microbial biomass carbon (SMBC) by the fumigation extraction method (VANCE; BROOKES; JENKINSON, 1987); b) soil basal respiration $\left(\mathrm{C}-\mathrm{CO}_{2}\right)$ by quantification of the soil $\mathrm{CO}_{2}$ released (JENKINSON; POWLSON, $1976)$; c) microbial quotient ( $q$ MIC) obtained by the relation between SMBC and total organic carbon (TOC); and d) metabolic quotient $\left(q \mathrm{CO}_{2}\right)$ calculated by the $\mathrm{C}-\mathrm{CO}_{2}$ to $\mathrm{SMBC}$ ratio (ANDERSON; DOMSCH, 1993).

Ten random maize plants in the evaluation area of the plots were marked at the $\mathrm{R}_{1}$ phenological growth stage (TOLLENAAR, 1992). These plants were evaluated at the $\mathrm{R}_{6}$ stage for leaf area (LA), plant height $(\mathrm{PH})$, stem base diameter (SD), ear diameter (ED), ear length (EL), number of grain rows per ear (NRE), and number of grains per row
(NGR). Subsequently, all plants in the evaluation area of the plots were harvested and threshed, and their grains were dried to a moisture of $13 \%$ and weighed to determine 1,000-grain weight (1000GW) and grain yield (GY) $\left(\mathrm{kg} \mathrm{ha}^{-1}\right)$ (TEIXEIRA; COSTA, 2010).

The data were subjected to analysis of variance by the $F$ test. The Dunnett's test $(p \leq 0.05)$ was applied to analyze the soil chemical and microbiological properties. The means of the soil properties and maize agronomic characteristics were subjected to Tukey's test $(\mathrm{p} \leq 0.05)$. The statistical analyses were performed using the ASSISTAT program (SILVA; AZEVEDO, 2016).

\section{RESULTS AND DISCUSSION}

The effect of the interaction between the biological fertilizer and soil cover plants was not significant; however, these factors affected the soil chemical and microbiological properties and the maize agronomic characteristics evaluated in both crop seasons (Tables 2, 3, 4, and 5).

The soils cultivated with maize showed higher fertility in the two evaluated crop seasons when compared to that of the forest fragment (control). The biological fertilizer used had no significant effects on the soil fertility, however, the use of millet as soil cover plant increased the potassium concentration in the 2015-2016 crop season (Table 2).

Table 2. Soil chemical properties ( 0 to $0.20 \mathrm{~m}$ layer) as a function of biological fertilizer and cover plants in the 2015-2016 crop season, using a forest fragment as a natural control.

\begin{tabular}{|c|c|c|c|c|c|c|c|c|c|}
\hline $\begin{array}{l}\text { Biological } \\
\text { fertilizer }\end{array}$ & Cover plant & \multicolumn{8}{|c|}{ Dunnett's test $(\mathrm{p} \leq 0,05)$} \\
\hline \multirow{3}{*}{ With } & Millet & 6.6 & $23.5 b$ & $2.6 b$ & $117.3 \mathrm{a}$ & $3.7 \mathrm{a}$ & $2.0 \mathrm{~b}$ & $1.5 \mathrm{~b}$ & 7.5 \\
\hline & Crotalaria & 6.7 & $23.2 b$ & $3.5 b$ & $117.3 \mathrm{a}$ & $3.3 b$ & $2.0 \mathrm{a}$ & $1.5 \mathrm{~b}$ & 7.1 \\
\hline & Fallow & 6.5 & $24.8 b$ & $3.5 b$ & $39.1 \mathrm{~b}$ & $3.7 \mathrm{a}$ & $2.0 \mathrm{~b}$ & $1.4 \mathrm{~b}$ & 7.3 \\
\hline Without & Fallow & 6.5 & $22.2 b$ & $5.1 \mathrm{a}$ & $39.1 b$ & $3.2 b$ & $2.2 \mathrm{a}$ & $1.4 \mathrm{~b}$ & 7.0 \\
\hline \multicolumn{2}{|c|}{ Forest fragment } & 6.4 & $30.5 \mathrm{a}$ & $0.7 \mathrm{~b}$ & $39.1 \mathrm{~b}$ & $2.3 \mathrm{~b}$ & $1.1 \mathrm{~b}$ & $3.3 \mathrm{a}$ & 6.9 \\
\hline \multicolumn{2}{|c|}{ Biological fertilizer } & \multicolumn{8}{|c|}{ Tukey's test $(\mathrm{p} \leq 0,05)$} \\
\hline \multicolumn{2}{|l|}{ With } & 6.6 & 23.8 & 3.2 & 78.2 & 3.6 & 2.0 & 1.5 & 7.3 \\
\hline \multicolumn{2}{|l|}{ Without } & 6.6 & 22.7 & 4.5 & 78.2 & 3.2 & 1.7 & 1.5 & 6.6 \\
\hline \multicolumn{2}{|l|}{$\mathrm{CV}(\%)$} & 4.1 & 8.9 & 63.8 & 22.7 & 20.8 & 24.9 & 10.4 & 12.9 \\
\hline
\end{tabular}

Means followed by the same letter in the column do not differ statistically by the Dunnett's test $(p \leq 0.05)$ and Tukey's test $(p \leq 0.05)$. 
In the subsequent crop season (2016-2017), the use of biological fertilizer and soil cover plants continued to increase the soil fertility when compared to the control (forest fragment), presenting higher $\mathrm{pH}$ and higher phosphorus, potassium, and calcium concentration (Table 3 ). This denotes the benefits of using this management in maize production systems in the second crop season.

Table 3. Soil chemical properties ( 0 to $0.20 \mathrm{~m}$ layer) as a function of biological fertilizer and cover plants in the 2016-2017 crop season, using a forest fragment as a natural control.

\begin{tabular}{|c|c|c|c|c|c|c|c|c|c|}
\hline \multirow{3}{*}{$\begin{array}{l}\text { Biological } \\
\text { fertilizer }\end{array}$} & \multirow{3}{*}{ Cover plants } & \multicolumn{8}{|c|}{ Dunnett's test $(\mathrm{p} \leq 0,05)$} \\
\hline & & \multirow{2}{*}{$\begin{array}{c}\mathrm{pH} \\
\mathrm{CaCl}_{2}\end{array}$} & \multirow{2}{*}{$\begin{array}{c}\mathrm{OM} \\
\mathrm{g} \mathrm{kg}^{-1}\end{array}$} & $P$ & $\mathrm{~K}$ & $\mathrm{Ca}$ & $\mathrm{Mg}$ & $\mathrm{H}+\mathrm{Al}$ & $\mathrm{T}$ \\
\hline & & & & \multicolumn{2}{|c|}{$----\mathrm{mg} \mathrm{dm}^{-3}$--- } & \multicolumn{4}{|c|}{ - $\mathrm{cmol}_{\mathrm{c}} \mathrm{dm}^{-3}$} \\
\hline \multirow{4}{*}{ With } & Millet & $5.7 \mathrm{a}$ & $27.3 \mathrm{~b}$ & $6.3 \mathrm{a}$ & $117.3 \mathrm{a}$ & $4.3 \mathrm{a}$ & 1.3 & $2.7 \mathrm{~b}$ & $8.6 \mathrm{~b}$ \\
\hline & Crotalaria & $5.7 \mathrm{a}$ & $28.0 \mathrm{~b}$ & $2.7 \mathrm{~b}$ & $117.3 \mathrm{a}$ & $4.2 \mathrm{a}$ & 1.2 & $2.3 \mathrm{~b}$ & $8.0 \mathrm{~b}$ \\
\hline & Fallow & $5.8 \mathrm{a}$ & $27.7 \mathrm{~b}$ & $4.3 b$ & $78.2 \mathrm{a}$ & $4.3 \mathrm{a}$ & 1.3 & $2.3 b$ & $8.1 \mathrm{~b}$ \\
\hline & Millet & $5.4 \mathrm{a}$ & $27.0 \mathrm{~b}$ & $6.5 \mathrm{a}$ & $117.3 \mathrm{a}$ & $4.1 b$ & 1.3 & $2.4 \mathrm{~b}$ & $8.1 b$ \\
\hline \multirow[t]{2}{*}{ Without } & Crotalaria & $5.5 \mathrm{a}$ & $25.3 \mathrm{~b}$ & $4.6 \mathrm{~b}$ & $78.2 \mathrm{a}$ & $4.3 \mathrm{a}$ & 1.2 & $2.6 \mathrm{~b}$ & $8.3 b$ \\
\hline & Fallow & $5.5 \mathrm{a}$ & $26.7 \mathrm{~b}$ & $4.2 \mathrm{~b}$ & $78.2 \mathrm{a}$ & $4.1 b$ & 1.3 & $2.6 \mathrm{~b}$ & $8.2 b$ \\
\hline \multicolumn{2}{|l|}{ Forest fragment } & $5.0 \mathrm{~b}$ & $39.3 \mathrm{a}$ & $0.7 \mathrm{~b}$ & $39.1 \mathrm{~b}$ & $3.8 \mathrm{~b}$ & 1.2 & $4.3 \mathrm{a}$ & $9.4 \mathrm{a}$ \\
\hline \multicolumn{2}{|c|}{ Biological fertilizer } & \multicolumn{8}{|c|}{ Tukey's test $(\mathrm{p} \leq 0,05)$} \\
\hline \multicolumn{2}{|l|}{ With } & $5.7 \mathrm{a}$ & 27.7 & 4.2 & 117.3 & 4.2 & 1.3 & 2.4 & 8.2 \\
\hline \multicolumn{2}{|l|}{ Without } & $5.5 \mathrm{~b}$ & 26.3 & 5.1 & 78.4 & 4.2 & 1.2 & 2.5 & 8.2 \\
\hline \multicolumn{10}{|l|}{ Cover of soil } \\
\hline \multicolumn{2}{|l|}{ Millet } & 5.6 & 27.2 & 6.4 & $117.3 \mathrm{a}$ & 4.2 & 1.3 & 2.5 & 8.3 \\
\hline \multicolumn{2}{|l|}{ Crotalaria } & 5.6 & 26.7 & 3.6 & $78.3 b$ & 4.2 & 1.2 & 2.4 & 8.1 \\
\hline \multicolumn{2}{|l|}{ Fallow } & 5.7 & 27.2 & 4.3 & $78.2 b$ & 4.2 & 1.3 & 2.4 & 8.1 \\
\hline \multicolumn{2}{|l|}{ CV (\%) } & 1.59 & 6.52 & 54.13 & 19.1 & 3.7 & 5.7 & 17.4 & 4.8 \\
\hline
\end{tabular}

Means followed by the same letter in the column do not differ statistically by the Dunnett's test $(p \leq 0.05)$ and Tukey's test $(p \leq 0.05)$.

The biological fertilizer had no effect on soil chemical properties of the experimental field in the 2015-2016 crop season. However, in the 2016-2017 crop season, the soil without biological fertilizer had lower $\mathrm{pH}$ (5.5), and that with the fertilizer had a lower decrease in soil pH (5.7) (Tables 2 and 3).

The highest potassium concentration (117.2 $\mathrm{mg} \mathrm{dm}{ }^{-3}$ ) was found in the soil covered with millet in the 2015-2016 crop season (Table 2), with similar results $\left(117.3 \mathrm{mg} \mathrm{dm}^{-3}\right)$ in the following crop season (Table 3 ). These results are higher than those found in the soil covered with crotalaria $\left(78.2 \mathrm{mg} \mathrm{dm}^{-3}\right)$ and in the fallow area $\left(78.2 \mathrm{mg} \mathrm{dm}^{-3}\right)$ in the last crop season.

Andreotti et al. (2008) evaluated the chemical changes of a Latossolo Vermelho (Oxisol) under notillage system, using Mucuna deeringiana, Crotalaria juncea, Setaria incana, Pennisetum glaucum, and Eleusine gracilis as cover plants, and found higher soil fertility due to nutrient cycling by organic matter decomposition on the soil surface, presenting a $\mathrm{K}$ concentration of $312.8 \mathrm{mg} \mathrm{dm}^{-3}$, mainly with the millet, which has high potassium cycling capacity.

This potassium concentration is higher than the highest one found in the present study using millet $\left(156.4 \mathrm{mg} \mathrm{dm}^{-3}\right)$ in the $2015 / 2016$ crop season, which was the first maize season grown in no-tillage system. Andreotti et al. (2008) evaluated a soil that had been under no-tillage for five years before their experiment and found higher dry matter production and release of elements such as $\mathrm{Ca}^{2+}$ and $\mathrm{Mg}^{2+}$ by soil cover plants, which contributed to nutrient cycling. Perin et al. (2010) evaluated millet and crotalaria as cover plant growing singly and intercropped, and found similar nutrient release in both crop systems for $\mathrm{P}, \mathrm{K}, \mathrm{Ca}$, and $\mathrm{Mg}$.

Torres et al. (2008) evaluated dry matter production and nutrient releases by soil cover plants and found higher fertility, mainly regarding $\mathrm{N}$ and $\mathrm{K}$ nutrients, and higher nutrient mineralization $(\mathrm{N}, \mathrm{P}$, $\mathrm{Ca}, \mathrm{Mg}$, and $\mathrm{S}$ ) in a Latossolo Vermelho (Oxisol) when compared to the soil of the control. Millet and crotalaria were the soil cover plants with the highest dry matter production and nutrient accumulation in the second crop season. Torres et al. (2008) reported similar results; they found higher $\mathrm{K}$ concentration with millet and crotalaria in the 2015/2016 crop season, and with single millet in the 2016/2017 crop season. Perin at al. (2010) found higher efficiency in $\mathrm{K}$ cycling when using millet as soil cover plant; the use of crotalaria resulted in higher efficiency in $\mathrm{Ca}$ and $\mathrm{Mg}$ cycling.

Jakelaitis et al. (2008) evaluated chemical properties of an Argissolo Vermelho-Amarelo (Ultisol) and found improvements in soil chemical quality and fertility, mainly regarding the $\mathrm{K}, \mathrm{Ca}, \mathrm{Mg}$, $\mathrm{Cu}$, and $\mathrm{Zn}$ nutrients, using maize in no-tillage system for five crop seasons. They also found improvements in soil physical and microbiological properties using no-tillage system, reaching similar characteristics to those of natural environments. 
The soil chemical indicators varied little due to the use of biological fertilizer and cover plants, except for $\mathrm{K}$ concentration, which was higher in the soil with millet. Carneiro et al. (2009) found little variation in chemical indicators, but lower $\mathrm{H}+\mathrm{Al}$, $\mathrm{Ca}, \mathrm{Mg}$, and $\mathrm{K}$ concentrations in soils treated with lime and mineral fertilization when compared to the soil of a natural forest.

The soil cultivated with maize had lower organic matter content than that of the forest fragment (control area) in both crop seasons. However, the organic matter was approximately $15 \%$ higher in the second crop season than in the first (Tables 2 and 3). It was due to the combined effects of biological fertilizer, organic matter produced by the cover plants, and maize crop residues produced over the time.

The no-tillage system assists in increasing or maintaining soil chemical and microbiological quality, since the conventional tillage system affects the organic matter. The soil microorganisms responsible for fragmenting and decomposing organic matter are very sensitive to environmental changes caused by agricultural practices. Thus, organic matter decomposition, nutrient cycling, soil aeration, and soil aggregation can be minimized using no-tillage system and soil cover plants that produce high amounts of biomass (SOUSA NETO et al., 2008). Contrastingly, the conventional tillage system is responsible for reducing $30 \%$ of the plant cover on the soil surface, decreasing the soil protection time and increasing soil carbon losses (MAHL et al., 2008).

The soil of the control area had higher total organic carbon contents (TOC) (31\%), microbial biomass carbon (SMBC) (423\%), microbial quotient ( $q \mathrm{MIC})(313 \%)$, and basal respiration $\left(\mathrm{C}-\mathrm{CO}_{2}\right)$ $(129 \%)$ than that cultivated with maize in the 20152016 crop season; and higher TOC (37\%), SMBC $(138 \%)$, and $q \mathrm{MIC}(72 \%)$ than the cultivated soils in the 2016-2017 crop season (Table 4).

Table 4. Soil microbiological properties $(0$ to $0.10 \mathrm{~m})$ as a function of biological fertilizer and cover plants in the 20152016 and 2016-2017 crop seasons, using a forest fragment as a natural control.

\begin{tabular}{|c|c|c|c|c|c|c|c|c|c|c|c|}
\hline \multirow{3}{*}{$\begin{array}{l}\text { Biological } \\
\text { fertilizer }\end{array}$} & \multirow{3}{*}{ Cover plants } & \multicolumn{10}{|c|}{ Dunnett's test $(\mathrm{p} \leq 0.05)$} \\
\hline & & \multicolumn{5}{|c|}{ Season 2015-2016 } & \multicolumn{5}{|c|}{ Season 2016-2017 } \\
\hline & & TOC & SMBC & $q \mathrm{MIC}$ & $\mathrm{C}-\mathrm{CO}_{2}$ & $q \mathrm{CO}_{2}$ & TOC & SMBC & $q \mathrm{MIC}$ & $\mathrm{C}-\mathrm{CO}_{2}$ & $q \mathrm{CO}_{2}$ \\
\hline \multirow{3}{*}{ With } & Millet & $13.6 \mathrm{~b}$ & $95.4 \mathrm{~b}$ & $0.7 b$ & $0.4 \mathrm{~b}$ & $3.9 \mathrm{~b}$ & $15.9 \mathrm{~b}$ & $177.7 \mathrm{~b}$ & $1.1 \mathrm{a}$ & 0.4 & $3.0 \mathrm{~b}$ \\
\hline & Crotalaria & $13.4 \mathrm{~b}$ & $77.9 b$ & $0.6 b$ & $0.2 b$ & $2.8 \mathrm{~b}$ & $16.2 \mathrm{~b}$ & $130.8 b$ & $0.8 b$ & 0.4 & $3.2 \mathrm{~b}$ \\
\hline & Fallow & $14.4 \mathrm{~b}$ & $133.1 b$ & $0.9 b$ & $0.5 b$ & $3.5 b$ & $16.1 \mathrm{~b}$ & $112.3 b$ & $0.7 \mathrm{~b}$ & 0.6 & $5.8 \mathrm{a}$ \\
\hline \multirow{3}{*}{ Without } & Millet & $12.5 b$ & $80.5 b$ & $0.7 b$ & $0.4 \mathrm{~b}$ & $4.8 \mathrm{a}$ & $15.7 \mathrm{~b}$ & $125.5 b$ & $0.8 b$ & 0.6 & $5.6 \mathrm{a}$ \\
\hline & Crotalaria & $14.2 \mathrm{~b}$ & $67.4 \mathrm{~b}$ & $0.5 b$ & $0.3 b$ & $4.5 \mathrm{a}$ & $15.4 \mathrm{~b}$ & $156.4 \mathrm{~b}$ & $1.0 \mathrm{a}$ & 0.4 & $2.8 \mathrm{~b}$ \\
\hline & Fallow & $12.8 b$ & $49.5 b$ & $0.4 \mathrm{~b}$ & $0.3 b$ & $7.4 \mathrm{a}$ & $14.7 \mathrm{~b}$ & $114.3 b$ & $0.8 b$ & 0.6 & $4.3 b$ \\
\hline Forest fragm & & $17.7 \mathrm{a}$ & $439.3 \mathrm{a}$ & $2.6 \mathrm{a}$ & $0.8 \mathrm{a}$ & $1.9 \mathrm{~b}$ & $21.4 \mathrm{a}$ & $324.7 \mathrm{a}$ & $1.5 \mathrm{a}$ & 0.5 & $1.5 \mathrm{~b}$ \\
\hline \multicolumn{2}{|c|}{ Biological fertilizer } & \multicolumn{10}{|c|}{ Tukey's test $(\mathrm{p} \leq 0,05)$} \\
\hline \multirow{2}{*}{\multicolumn{2}{|c|}{$\begin{array}{l}\text { With } \\
\text { Without }\end{array}$}} & 13.8 & $102.1 \mathrm{a}$ & $0.7 \mathrm{a}$ & 0.4 & $3.4 \mathrm{~b}$ & 16.0 & 140.2 & 0.9 & 0.5 & 4.0 \\
\hline & & 13.2 & $65.8 \mathrm{~b}$ & $0.5 b$ & 0.3 & $5.6 \mathrm{a}$ & 15.3 & 132.1 & 0.9 & 0.5 & 4.2 \\
\hline \multicolumn{12}{|l|}{ Cover of soil } \\
\hline \multicolumn{2}{|l|}{ Millet } & 13.0 & 88.0 & $0.7 \mathrm{a}$ & $0.4 \mathrm{ab}$ & $4.3 \mathrm{ab}$ & 15.8 & 151.6 & 0.9 & 0.5 & $4.3 \mathrm{ab}$ \\
\hline \multicolumn{2}{|l|}{ Crotalaria } & 13.8 & 72.7 & $0.5 b$ & $0.3 \mathrm{~b}$ & $3.7 \mathrm{~b}$ & 15.8 & 143.6 & 0.9 & 0.4 & $3.0 \mathrm{~b}$ \\
\hline \multicolumn{2}{|l|}{ Fallow } & 13.6 & 91.3 & $0.6 \mathrm{ab}$ & $0.4 \mathrm{a}$ & $5.5 \mathrm{a}$ & 15.4 & 113.3 & 0.7 & 0.6 & $5.0 \mathrm{a}$ \\
\hline \multicolumn{2}{|l|}{$\mathrm{CV}(\%)$} & 8.9 & 9.9 & 10.2 & 19.7 & 24.1 & 7.1 & 30.3 & 36.1 & 25.3 & 38.9 \\
\hline
\end{tabular}

Means followed by the same letter in column do not differ statistically for the Dunnett's test $(p \leq 0.05)$ and Tukey's test $(p \leq 0.05)$. Total organic carbon (TOC; $\left.\mathrm{g} \mathrm{kg}^{-1}\right)$, soil microbial biomass carbon (SMBC; $\mathrm{mg} \mathrm{C}$ microbial $\mathrm{kg}^{-1} \mathrm{soil}$ ), microbial quotient $(q \mathrm{MIC} ; \%)$, soil basal respiration $\left(\mathrm{C}-\mathrm{CO}_{2} ; \mathrm{mg}\right.$ of $\mathrm{C}-\mathrm{CO}_{2} \mathrm{~kg}^{-1}$ soil hour $\left.{ }^{-1}\right)$, and metabolic quotient $\left(q \mathrm{CO}_{2} ; \mathrm{mg} \mathrm{C}^{-} \mathrm{CO}_{2}\right.$ $\left.\mathrm{g}^{-1} \mathrm{SMBC} \mathrm{h}^{-1}\right)$.

The use of biological fertilizer improved the soil microbiological properties, showing the important effect of using biological compounds from bovine manure on the development of microorganism populations in the experimental soil. The SMBC found in the 2016-2017 crop season (140.2 mg C microbial $\mathrm{kg}^{-1}$ soil) was $37.32 \%$ higher than that found in the 2015-2016 crop season (102.1 $\mathrm{mg} \mathrm{C}$ microbial $\mathrm{kg}^{-1}$ soil) when using the biological fertilizer (Table 4), but it is still low for a dystrophic Latossolo Vermelho (Oxisol).

The soil cultivated with maize presented lower soil microbial biomass carbon (SMBC). Jakelaitis et al. (2008) found similar results when comparing soils cultivated with crops in no-tillage system to soils with natural vegetation. According to Silva et al. (2010), the more intensive the soil management the lower the carbon fixation by the microbial biomass, because carbon losses are intensified under stress conditions.

Moreover, the complexity, amount, and quality of the organic residues on the soil affect the microbial activity, slowing decomposition of lesscomplex organic matter and soil carbon fixation. Therefore, SMBC may be sensitive even to the introduction of a new plant cover in the crop rotation (BELO et al., 2012). Thus, associating agricultural practices, such as biological fertilizer and cover 
plants, can improve soil properties. Zhao et al. (2009) found a high SMBC in soils cultivated with cover plants and subjected to biological fertilizer combined with mineral fertilizer.

Mendes, Sousa, and Junior (2015) developed a table of interpretation classes for microbiological quality indicators for a Latossolo Vermelho (Oxisol) of the Cerrado biome in Brazil and established that the SMBC and the soil basal respiration are adequate when they are higher than $400 \mathrm{mg} \mathrm{kg}^{-1}$ and $100 \mathrm{mg}$ $\mathrm{kg}^{-1}$, respectively. Based on these values, the results of the indicators found in the present study for the cultivated soils were within the lower class.

The biological fertilizer and cover plants affected positively and significantly these indicators in both crop seasons. Several factors may have contributed to these results, such as the lower average precipitation and temperature in the first crop season (Figure 1).

The soil with millet had a $q \mathrm{MIC}$ of $0.7 \%$ in the 2015-2016 crop season, which was higher than those of the crotalaria $(0.5 \%)$ and the fallow area $(0.6 \%)$. In the 2016/2017 crop season, the means of $q \mathrm{MIC}$ were statistically similar by the Tukey's test (Table 4). The use of the no-tillage system increased the soil organic matter content in both crop seasons; this organic matter was a substrate for the development of microorganisms that were already present in the area and for the ones introduced by the biological fertilizer.

The soil $q \mathrm{MIC}$ expresses the SMBC to TOC ratio, indicating the amount of soil carbon immobilized by microorganisms; it is sensitive to changes in the crop system (SILVA et al., 2010; DUARTE et al., 2014). In the present study, the values of this property in the soils cultivated with maize were lower than $1 \%$. According to Jakelaitis et al. (2008), this denotes that some factors, such as nutrient limiting to microorganisms, homogeneity of the organic matter, and water reducing, cause soil microbial stress. Jenkinson and Ladd (1981) reported that the $q \mathrm{MIC}$ of balanced soils must be between $1 \%$ and $4 \%$ of the TOC, such as that of the forest fragment evaluated in the present study.

According to the metabolic quotient $\left(q \mathrm{CO}_{2}\right)$, the soil of the control area had higher quality than that cultivated with maize, whose $q \mathrm{CO}_{2}$ was $135 \%$ (2015/2016) and 175\% (2016-2017) higher than that of the soil without biological fertilizer and cover plants. Regarding the use of cover plants, the crotalaria residues in the soil cultivated with maize resulted in lower $q \mathrm{CO}_{2}$ at the first $\left(3.7 \mathrm{mg} \mathrm{C}-\mathrm{CO}^{2} \mathrm{~g}^{-}\right.$ $\left.{ }^{1} \mathrm{SMBC} \mathrm{h}^{-1}\right)$ and second $\left(3 \mathrm{mg} \mathrm{C}-\mathrm{CO}^{2} \mathrm{~g}^{-1} \mathrm{SMBC} \mathrm{h}^{-1}\right)$ crop seasons, followed by the millet at the first (4.3

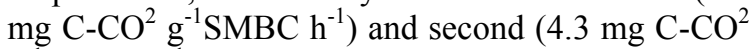
$\left.\mathrm{g}^{-1} \mathrm{SMBC}^{-1}\right)$ crop seasons, and the fallow area at the first (5.5 mg C-CO $\left.\mathrm{mg}^{-1} \mathrm{SMBC} \mathrm{h}^{-1}\right)$ and second ( $5 \mathrm{mg}$ $\left.\mathrm{C}-\mathrm{CO}^{2} \mathrm{~g}^{-1} \mathrm{SMBC} \mathrm{h}^{-1}\right)$ crop seasons. The $q \mathrm{CO}_{2}$ was $40 \%$ lower when using the biological fertilizer in the 2015-2016 crop season than that of the soil without biological fertilizer (Table 4). However, the soil with millet had the highest $q \mathrm{CO}_{2}$, indicating losses of carbon as $\mathrm{CO}_{2}$ by microbial respiration, presenting similar results to those found in the soil of the fallow area, in both crop seasons. The soil with crotalaria had lower SMBC than that with millet, but the metabolic activity of the microorganisms of the soil was more efficient when using this cover plant, as shown by the results of the plots with biological fertilizer (Table 4).

The use of biological fertilizer and cover plants (millet or crotalaria) resulted in higher SMBC and lower $\mathrm{CO}_{2}$ losses to the atmosphere when compared to the soil without the biological fertilizer and to the soil of the fallow area. Moreover, these managements improved the soil microbiological quality, which is responsible for decomposition of organic matter and mineralization of nutrients in the soil.

The basal respiration $\left(\mathrm{C}-\mathrm{CO}_{2}\right)$ in the soils with millet, fallow area, and forest fragment was higher in the 2015-2016 crop season. According to Silva et al. (2010), microbial properties are sensitive to changes in natural and crop systems due to soil management practices, temperature, and soil moisture. Low $\mathrm{C}-\mathrm{CO}_{2}$ is commonly found in natural environments and in minimum tillage, no-tillage, and agriculture-livestock integration systems (ALVES et al., 2011; MENDES; SOUSA; JUNIOR, 2015).

Soils with natural vegetation, as in the forest fragment, usually have more complex organic residues and less readily available carbon, resulting in a low $\mathrm{C}-\mathrm{CO}_{2}$ emission by microorganisms. However, the high microbial respiration found in the soil of the forest fragment, in the soil with millet, and in the soil of the fallow area in the 2015/2016 crop season may indicate a greater release of nutrients to the soil due to the high organic matter decomposition. Thus, analyzing this property alone does not provide complete information on soil microbial conditions; therefore, the amount of $\mathrm{CO}_{2}$ released per unit of microbial carbon from the soil should be determined (ALVES et al., 2011).

The $q \mathrm{CO}_{2}$ is the result of the $\mathrm{C}-\mathrm{CO}_{2}$ to $\mathrm{SMBC}$ ratio. The closer the $q \mathrm{CO}_{2}$ is to zero the lower the microbial stress. Environments under greater stress conditions, such as the fallow area, have greater carbon $\left(\mathrm{CO}_{2}\right)$ loss by microbial respiration (SILVA et al., 2010). The lowest $q \mathrm{CO}_{2}$ was found in the soil of the forest fragment and in that with crotalaria. Similarly, Jakelaitis et al. (2008) found lower $q \mathrm{CO}_{2}$ in a soil with native vegetation; and Belo et al. (2012) found lower metabolic efficiency of microorganisms in soils without vegetation cover.

According to Duarte et al. (2014), the less the respiration per unit of microbial carbon the more efficient the soil carbon fixation, indicating less stress conditions. Insam and Domsch (1988) reported that microbial respiration tends to decrease as the environment improves soil quality and stability;

Rev. Caatinga, Mossoró, v. 32, n. 3, p. 709 - 718, jul. - set., 2019 
therefore, the introduction of organic matter into the soil from cover plants can increase $q \mathrm{CO}_{2}$ (ALVES et al., 2011). Thus, an efficient analysis of each agricultural context is important.

The biological fertilizer had no significant effect on the maize vegetative and productive characteristics in the evaluated crop seasons. Probably, this was due to the short time of the experiment. However, the maize grain yield increased by $37 \%$ (with biological fertilizer) and $28 \%$ (without biological fertilizer) between the first to the second crop season (Table 5).

Table 5. Maize crop responses to biological fertilizer and soil cover plants in the 2015-2016 and 2016-2017 crop seasons.

\begin{tabular}{|c|c|c|c|c|c|c|c|c|c|}
\hline \multirow[b]{2}{*}{ Biological fertilizer } & \multicolumn{9}{|c|}{ Season 2015-2016 } \\
\hline & $\begin{array}{l}\text { LA } \\
\mathrm{m}^{2}\end{array}$ & $\begin{array}{c}\mathrm{PH} \\
\mathrm{m}\end{array}$ & \multicolumn{3}{|c|}{---------- cm ------------ } & NRE & NGR & $\begin{array}{c}1.000 \mathrm{GW} \\
\mathrm{g}\end{array}$ & $\begin{array}{c}\mathrm{GY} \\
\mathrm{kg} \mathrm{ha}^{-1}\end{array}$ \\
\hline With & 7.4 & 2.2 & 2.1 & 4.8 & 15.3 & 15.9 & 30.3 & 319.7 & $5,745.8$ \\
\hline Without & 7.6 & 2.2 & 2.2 & 4.8 & 15.6 & 16.1 & 31.1 & 316.9 & $6,034.1$ \\
\hline \multicolumn{10}{|l|}{ Cover plants } \\
\hline Millet & $7.5 \mathrm{ab}$ & 2.2 & 2.2 & $4.7 b$ & 15.2 & 15.7 & $29.8 b$ & 320.0 & $5,754.1 \mathrm{ab}$ \\
\hline Crotalaria & $7.9 \mathrm{a}$ & 2.2 & 2.1 & $4.8 \mathrm{a}$ & 15.7 & 15.9 & $31.6 \mathrm{a}$ & 315.6 & $6,251.2 \mathrm{a}$ \\
\hline Fallow & $7.1 \mathrm{~b}$ & 2.2 & 2.1 & $4.8 \mathrm{a}$ & 15.4 & 16.2 & $30.8 \mathrm{ab}$ & 319.3 & $5,664.5 \mathrm{~b}$ \\
\hline $\mathrm{CV}(\%)$ & 7.0 & 2.1 & 5.7 & 1.8 & 4.3 & 2.7 & 4.6 & 4.30 & 7.4 \\
\hline Biological fertilizer & \multicolumn{9}{|c|}{ Season 2016-2017 } \\
\hline With & 7.4 & 2.1 & 2.2 & 4.8 & 17.2 & 17.9 & 35.4 & 377.2 & $7,839.7$ \\
\hline Without & 7.4 & 2.1 & 2.2 & 4.8 & 17.6 & 18.1 & 36.1 & 377.0 & $7,750.8$ \\
\hline \multicolumn{10}{|l|}{ Cover plants } \\
\hline Millet & 7.3 & 2.1 & 2.3 & 4.8 & 17.2 & 17.7 & $34.8 \mathrm{~b}$ & 378.0 & $8,206.9 a$ \\
\hline Crotalaria & 7.0 & 2.2 & 2.3 & 4.9 & 17.7 & 17.9 & $36.6 \mathrm{a}$ & 376.0 & $8,217.5 \mathrm{a}$ \\
\hline Fallow & 7.9 & 2.1 & 2.2 & 4.9 & 17.4 & 18.2 & $35.8 \mathrm{ab}$ & 377.6 & $6,961.3 \mathrm{~b}$ \\
\hline CV (\%) & 10.4 & 5.0 & 5.7 & 1.8 & 3.8 & 2.4 & 4.0 & 2.35 & 10.7 \\
\hline
\end{tabular}

Means followed by the same letter in the column do not differ statistically by the Tukey's test $(p \leq 0.05)$. Leaf area (LA), plant height (PH), stem base diameter (SD), ear diameter (ED), ear length (EL), number of grain rows per ear (NRE), number of grains per row (NGR), 1,000-grain weight (1000GW), and grain yield (GY).

Crotalaria is a nitrogen-fixing plant, thus, the use of crotalaria as soil cover plant resulted in higher maize leaf area, ear diameter, number of grains per row, and grain yield in the 2015-2016. Moreover, it resulted in higher 1,000-grain weight and grain yield in the 2016-2017 crop season when compared to the first. However, the use of millet as soil cover plant increased the maize grain yield in the 2016-2017 crop season, probably by increasing the soil potassium concentration and organic matter (Tables 2,3 , and 5 ).

The maize grain yield was approximately $43 \%$ higher when using millet and 32\% higher when using crotalaria as soil cover plant in the second crop season when compared to the first (Table 5). These results were due to the soil chemical (Tables 2 and 3) and microbiological improvements (Table 4) generated by the cover plants, and the higher precipitation in the second crop season (Figure 1).

Maize crops have high nutritional requirement, mainly nitrogen. The yield of the maize grown in soils with crotalaria as plant cover was higher than that of the maize grown in soils of the fallow area, in both crop seasons. These results were probably due to the atmospheric nitrogen fixation by symbiosis between crotalaria plants and fixing bacteria (Rhizobium spp.), which releases $\mathrm{N}$ gradually along the maize cycle (ANDREOTTI et al., 2008).
Andrioli et al. (2008) found higher grain yields of maize grown in soils covered with crotalaria residues than in soils covered with millet residues. Silva et al. (2007) also found higher maize yield in rotations with Crotalaria sp., and higher need for mineral nitrogen fertilization when the maize was rotated with millet, they recommended the use of Crotalaria sp. as an alternative for nitrogen fertilization in maize crops.

The soil managements used in the present study showed the importance of biological fertilizers and soil cover plants to improve soil chemical and microbiological properties, and to increase maize yield due to the crotalaria organic matter.

\section{CONCLUSION}

The use of biological fertilizer and soil cover plants have a practical potential to increase soil chemical and microbial properties in long-term managements. The soil properties at the second crop season showed a slight improvement when compared to the first crop season.

The highest maize yields were found in plants grown on plant residues of crotalaria in the 20152016 crop season, and in plants grown on plant residues of crotalaria or millet in the 2016-2017 crop season. The maize agronomic characteristics had no response to the biological fertilizer. 


\section{ACKNOWLEDGEMENTS}

The authors thank the Conselho Nacional de Desenvolvimento Científico e Tecnológico (CNPq) for granting a scholarship for the first author.

\section{REFERENCES}

ABERA, T. et al. Effects of crop rotation and N-P fertilizer rate on grain yield and related characteristics of maize and soil fertility at Bako, Western Oromia, Ethiopia. East African Journal of Sciences, v. 3, n. 1. p. 70-79, 2009.

ALVES, T. S. et al. Biomassa e atividade microbiana de solo sob vegetação nativa e diferentes sistemas de manejos. Acta Scientiarum Agronomy, v. 33, n. 2, p. 341-347, 2011.

ANDERSON, T. H.; DOMSCH, K. H. The metabolic quotient for $\mathrm{CO}_{2}\left(q \mathrm{CO}_{2}\right)$ as a specific activity parameter to assess the effects of environmental conditions, such as $\mathrm{pH}$, on the microbial biomass of forest soils. Soil Biology and Biochemistry, v. 25, n. 3, p. 393-395, 1993.

ANDREOTTI, M. et al. Produtividade do milho safrinha e modificações químicas de um Latossolo em sistema plantio direto em função de espécies de cobertura após calagem superficial. Acta Scientiarum Agronomy, v. 30, n. 1, p. 109-115, 2008.

ANDRIOLI, I. et al. Produção de milho em plantio direto com adubação nitrogenada e cobertura do solo na pré-safra. Revista Brasileira de Ciência do Solo, v. 32, n. 4, p. 1691-1698, 2008.

BELO, E. S. et al. Decomposição de diferentes resíduos orgânicos e efeito na atividade microbiana em um Latossolo Vermelho de Cerrado. Global Science and Technology, v. 5, n. 3, p. 107-116, 2012.

BEZERRA, L. L. et al. Avaliação da aplicação de biofertilizante na cultura do milho: crescimento e produção. Revista Verde, v. 3, n. 3, p. 131-139, 2008.

BHARDWAJ, A. K. et al. Ecological management of intensively cropped agro-ecosystems improves soil quality with sustained productivity. Agriculture, Ecosystems and Environment, v. 140, n. 3-4, p. 419-429, 2011

BOER, C. A. et al. Ciclagem de nutrientes por plantas de cobertura na entressafra em um solo de cerrado. Pesquisa Agropecuária Brasileira, v. 42, n. 9, p. 1269-1276, 2007.
CAPUANI, S. et al. Atividade microbiana em solos, influenciada por resíduos de algodão e torta de mamona. Revista Brasileira de Engenharia Agrícola e Ambiental, v. 16, n. 12, p. 1269-1274, 2012 .

CARNEIRO, M. A. C. et al. Atributos físicos, químicos e biológicos de solo de cerrado sob diferentes sistemas de uso e manejo. Revista Brasileira de Ciência do Solo, v. 33, n. 1, p. 147157, 2009.

COMPANHIA NACIONAL DE ABASTECIMENTO - CONAB. Acompanhamento da Safra Brasileira de Grãos. Brasília - DF: CONAB, 2019.

DUARTE, I. B. et al. Plantas de cobertura e seus efeitos na biomassa microbiana do solo. Acta Iguazu, v. 3, n. 2, p. 150-165, 2014.

EMPRESA BRASILEIRA DE PESQUISA AGROPECUÁRIA - EMBRAPA. Manual de métodos de análise de solo. 2. ed. Rio de Janeiro, RJ: Embrapa Solos, 2011. 230 p.

EMPRESA BRASILEIRA DE PESQUISA AGROPECUÁRIA - EMBRAPA. Sistema brasileiro de classificação de solos. 3. ed. Brasília, DF: Embrapa informação tecnológica, 2013. 353 p.

HARGREAVES, P.R. et al. Evaluating soil microbial biomass carbon as an indicator of longterm environmental change. Soil Biology and Biochemistry, v. 35, n. 3, p. 401-407, 2003.

INSAM, H.; DOMSCH, K. H. Relationship between soil organic carbon and microbial biomass on chronosequences of reclamation sites. Microbial Ecology, v. 15, n. 4, p. 177-188, 1988.

JAKELAITIS, A. et al. Qualidade da camada superficial de solo sob mata, pastagens e áreas cultivadas. Pesquisa Agropecuária Tropical, v. 38 , n. 2, p. 118-127, 2008.

JENKINSON, D. S.; LADD, J. N. Microbial biomass in soil: measurement and turnover. In: PAUL, E. A.; LADD, J. N. (Eds.). Soil Biochemistry. New York: Marcel Dekker, 1981. v. 5, p. 415-471.

JENKINSON, D. S.; POWLSON, D. S. The effects of biocidal treatments on metabolism in soil - V: A method for measuring soil biomass. Soil Biology \& Biochemistry, v. 8, n. 3, p. 209-213, 1976.

LIU, Z. at al. Soil quality assessment of yellow clayey paddy soils with different productivity. 
Biology and Fertility of Soils, v. 50, n. 3, p. 537-48, 2014.

MAHL, D. et al. Resistência do solo à penetração, cobertura vegetal e produtividade do milho em plantio direto escarificado. Acta Scientiarum Agronomy, v. 30, n. 5, p. 741-747, 2008.

MEDEIROS, M. B.; LOPES, J. S. Biofertilizantes líquidos e sustentabilidade agrícola. Bahia Agrícola, v. 7, n. 3, p. 24-26, 2006.

MENDES, I. C.; SOUSA, D. M. G.; JUNIOR, F. B. R. Bioindicadores de qualidade de solo: dos laboratórios de pesquisa para o campo. Cadernos de Ciência \& Tecnologia, v. 32, n. 1-2, p. 191-209, 2015.

PERIN, A. et al. Acúmulo e liberação de P, K, Ca e Mg em crotalária e milheto solteiros e consorciados. Revista Ceres, v. 57, n. 2, p. 274-281, 2010.

SILVA, E. C. et al. Análise econômica da adubação nitrogenada no milho sob plantio direto em sucessão a plantas de cobertura em Latossolo Vermelho. Acta Scientiarum Agronomy, v. 29, n. 4, p. 445-452, 2007.

SILVA, F. A. S.; AZEVEDO, C. A. V. The Assistat Software Version 7.7 and its use in the analysis of experimental data. African Journal of Agricultural Research, v. 11, n. 39, p. 3733-3740, 2016.

SILVA, R. R. et al. Biomassa e atividade microbiana em solo sob diferentes sistemas de manejo na região fisiográfica Campos das Vertentes - MG. Revista Brasileira de Ciência do Solo, v. 34, n. 5, p. 15851592, 2010.

SOUSA NETO, E. L. et al. Atributos físicos do solo e produtividade de milho em resposta a culturas de pré-safra. Pesquisa Agropecuária Brasileira, v. 43, n. 2, p. 255-260, 2008.

SOUSA, D. M. G.; LOBATO, E. Cerrado: correção do solo e adubação. 2. ed. Brasília, DF: Embrapa Cerrados, 2004. 416 p.

TEIXEIRA, F. V.; COSTA, F. M. Caracterização de Recursos Genéticos de Milho. 1. ed. Brasília, DF: Embrapa Milho e Sorgo, 2010. 10 p

TOLLENAAR, M. Is low density a stress in maize. Maydica, v. 37, s/n., p. 305-311, 1992.

TORRES, J. L. R. et al. Produção de fitomassa por plantas de cobertura e mineralização de seus resíduos em plantio direto. Pesquisa Agropecuária Brasileira, v. 43, n. 3, p. 421-428, 2008.

VANCE, E. D.; BROOKES, P. C.; JENKINSON, D. S. An extraction method for mesuring soil microbial biomass-C. Soil Biology \& Biochemistry, v. 19, n. 6, p. $703-707,1987$.

XU, Y. et al., Effects of long-term fertilization management practices on soil microbial carbon and microbial biomass in paddy soil at various stages of rice growth. Revista Brasileira de Ciêencia do Solo, v. 42, n. 01, p. 70-111, 2018.

ZERIHUN, A.; HAILE, D. The effect of organic and inorganic fertilizers on the yield of two contrasting soybean varieties and residual nutrient effects on a subsequent finger millet crop. Agronomy, v. 7, n. 42, p. 2-15, 2017.

ZHAO, Y. et al. The effects of two organic manures on soil properties and crop yields on a temperate calcareous soil under a wheat-maize cropping system. European Journal of Agronomy, v. 31, n. 1 , p. $36-42,2009$ 